\title{
STUDIES ON BIOSYNTHESIS OF KASUGAMYCIN. VI
}

\author{
SOME RELATIONSHIPS BETWEEN THE INCORPORATION OF \\ ${ }^{14} \mathrm{C}$-COMPOUNDS AND THE PRODUCTION OF KASUGAMYCIN
}

\author{
Tsutomu Sawa, Yasuo Fukagawa, Ikuyo Homma, \\ Tomio Takeuchi and Hamao Umezawa \\ Institute of Microbial Chemistry, Shinagawa-ku, Tokyo
}

(Received for publication April 23, 1968)

\begin{abstract}
The biosynthesis of kasugamycin was studied with the purpose of increasing the fermentation yield of kasugamycin. Kasugamycin was stable in the cultured broth, if $\mathrm{pH}$ of the cultured liquid did not exceed 8.0. Kasugamycin in the cultured broth was proved to show no inhibition of kasugamycin production. Glucose and glycine added to the medium during kasugamycin production were rapidly metabolized. In parallel with the rapid disappearance of these compounds, they were incorporated into kasugamycin, but their metabolic products were not used for synthesis of kasugamycin. Myo-inositol was slowly consumed and incorporated into kasugamycin. There was $26 \%$ left in the medium 200 minutes after addition of myo-inositol. Thus, it was suggested that myo-inositol added caused some change in utilization of this compound. Among 3-day, 6-day and 10-day cultured broths, the incorporation of ${ }^{14} \mathrm{C}$-glucose, ${ }^{14} \mathrm{C}$-glycine and ${ }^{14} \mathrm{C}$-myo-inositol were the highest in the 3-day culture broth. ${ }^{14} \mathrm{C}$-Glucose and ${ }^{14} \mathrm{C}$-myo-inositol were equally well incorporated at $\mathrm{pH} 5.0 \sim 7.5$ but the highest incorporation of ${ }^{14} \mathrm{C}-\mathrm{glycine}$ was shown at $\mathrm{pH} 6.5 \sim 7.0$. Optimal temperature for incorporation of ${ }^{14} \mathrm{C}-$ glucose, ${ }^{14} \mathrm{C}$-myo-inositol and ${ }^{14} \mathrm{C}$-glycine was found to be dependent on the grade of aeration.
\end{abstract}

As reported in previous papers ${ }^{1,2,3,4,5)}$, the kasugamine moiety (2,4-diamino- $2,3,4,6$ tetradeoxy-D-arabino-hexopyranose) of kasugamycin is biosynthesized from glucose probably through glucosamine derivatives, the carboxyformidoyl group (the side chain attached to kasugamine) from glycine without fragmentation, and the $\mathrm{D}$-inositol moiety from glucose through myo-inositol or its derivatives. It is speculated that nucleoside diphosphate (probably UDP) glucosamine or nucleoside diphosphate $\mathrm{N}$ acetylglucosamine may be an intermediate for synthesis of nucleoside diphosphate 4$\mathrm{N}$-carboxyformidoyl kasugamine which reacts with myo-inositol or its derivative to produce kasugamycin.

Kasugamycin is an antibiotic which is used for prevention of rice blast and the high production yield is required. It was hoped that biosynthetic studies eould result in yield improvement. However, neither addition of glycine nor myo-inositol to the medium raised the yield of kasugamycin, although about $20 \%$ of the glycine added during the production phase and about $50 \%$ of the myo-inositol added was incorporated into kasugamycin. Kasugamycin in the cultured broth was shown not to inhibit 
further kasugamycin production. Incorporation rates of glucose and myo-inositol were independent of $\mathrm{pH}$ but glycine was most incorporated at $\mathrm{pH} 6.5 \sim 7.0$ which was suggested to be the optimal $\mathrm{pH}$ for kasugamycin production. Incorporation of these compounds added at various phases of growth of a kasugamycin-producing strain suggested that glycine and glucose added were rapidly metabolized and did not increase production, also the productivity of the mycelium changed at various phases of the fermentation. These results are presented in this paper.

\section{Materials and Methods}

Maltose-soybean medium was used unless otherwise specified. It consisted of maltose $1.5 \%$, soybean meal $1.5 \%, \mathrm{~K}_{2} \mathrm{HPO}_{4} 0.1 \%, \mathrm{MgSO}_{2} \cdot 7 \mathrm{H}_{2} \mathrm{O} 0.1 \%$ and $\mathrm{NaCl} 0.3 \%$. Fermentation was generally performed on a reciprocal shaking machine $(8 \mathrm{~cm}$ amplitude and 120 strokes). U- ${ }^{14} \mathrm{C}-\mathrm{Glucose}(5.0 \mathrm{mc} / \mathrm{mM})$ and $\mathrm{U}-{ }^{14} \mathrm{C}-$ glycine $(10.2 \mathrm{mc} / \mathrm{mm})$ were purchased from Daiichi Pure Chemicals Co., Ltd. U-14C-Myo-inositol $(36.0 \mathrm{mc} / \mathrm{mm})$ and $1{ }^{14} \mathrm{C}-$ glycine $(9.9$ $\mathrm{mc} / \mathrm{mm}$ ) were purchased from the Radiochemical Center, Amersham.

${ }^{14} \mathrm{C}-$ Kasugamycin $\left(3.04 \times 10^{6} \mathrm{dpm}, 100 \mathrm{mg}\right)$ was prepared by the addition of $\mathrm{U}-{ }^{14} \mathrm{C}-\mathrm{glucose}$ $(20 \mu \mathrm{c})$ during the production phase.

For isolation of kasugamycin, the cultured broth was removed from a flask, immediately heated for 3 minutes at $100^{\circ} \mathrm{C}$ and centrifuged. The supernatant $(0.030 \mathrm{ml})$ was spotted on a Toyo filter paper No. $51(60 \times 60)$. This paper was subjected to high voltage paper electrophoresis at $3,500 \mathrm{~V}$ for 15 minutes with a buffer system of formic acid -acetic acid - water $(25: 75: 900)$ at $\mathrm{pH} 1.8$. The spot corresponding to kasugamycin was cut out and extracted with $2 \mathrm{ml}$ of warm distilled water twice. This aqueous extract was passed through a column of $2.0 \mathrm{ml}$ of Amberlite XE-100 resin in $\mathrm{NH}_{4}{ }^{+}$form and the adsorbed kasugamycin was eluted with $0.2 \mathrm{~N} \mathrm{NH}_{4} \mathrm{OH}$. In some experiments the extraction process was modified as described. The radioactivity was measured by a Beckman Liquid Scintillation System CPM-200 (LS-II).

\section{Results and Discussion}

Stability of kasugamycin in the cultured broth and its effect on production of kasugamycin :

S. kasugaensis was shakecultured at $27^{\circ} \mathrm{C}$ for 3 days in $125 \mathrm{ml}$ of the maltose-soybean medium in a $500-\mathrm{ml}$ llask, and $100 \mathrm{mg}$ of ${ }^{14} \mathrm{C}$-kasugamycin $\left(3.04 \times 10^{6} \mathrm{dpm}\right)$ was added. It was further shake-cultured and $1,2,3,4,6$ and 9 days after addition of ${ }^{14} \mathrm{C}$-kasugamycin, $2.0 \mathrm{ml}$ of the broth was taken. The total radioactivity of kasugamycin in

Table 1. Stability of ${ }^{14} \mathrm{C}$-kasugamycin in the cultured broth

\begin{tabular}{c|c|c|c|c|c}
\hline \multirow{2}{*}{$\begin{array}{c}\text { Days after } \\
\text { addition of } \\
{ }^{14} \text { C-kasugamycin }\end{array}$} & $\mathrm{pH}$ & \multicolumn{2}{|c|}{$\begin{array}{c}\text { High voltage paper* } \\
\text { electrophoresis }\end{array}$} & \multicolumn{2}{|c}{$\begin{array}{c}\mathrm{XE}-100 \text { resin** } \\
\left(\mathrm{NH}_{4}^{+}\right)\end{array}$} \\
\cline { 2 - 6 } & $\mathrm{dpm}$ & $\%$ & $\mathrm{dpm}$ & $\%$ \\
\hline 0 & 6.4 & 2,810 & 100 & $3.04 \times 10^{6}$ & 100 \\
1 & 6.4 & 2,813 & 100.1 & 2.99 & 98.4 \\
2 & 6.4 & 2,737 & 97.4 & 2.95 & 97.0 \\
3 & 6.4 & 2,769 & 98.5 & 3.03 & 99.7 \\
4 & 6.4 & 2,648 & 94.2 & 3.03 & 99.7 \\
6 & 8.0 & 2,187 & 77.8 & 2.64 & 86.8 \\
9 & 8.7 & 1,927 & 68.6 & 2.30 & 75.7 \\
\hline
\end{tabular}

* Each $0.15 \mathrm{ml}$ of the sample solutions was spotted on filter paper and subjected to high voltage paper electrophoresis. The radioactivity of the spot corresponding to kasugamycin was determined.

** Corrected for the total ${ }^{14} \mathrm{C}$-activity of the broth. each sample was determined. As shown in Table 1, during 4 days of the shaking culture no decomposition of ${ }^{14} \mathrm{C}$-kasugamycin was observed. Six days after addition of the radioactive kasugamycin, $\mathrm{pH}$ of the cultured broth became 8.0 or higher and 
slight decomposition was observed. Thus, kasugamycin in the cultured broth was shown to be stable if the $\mathrm{pH}$ of the broth was with the proper $\mathrm{pH}$ range.

The same kasugamycin-producing strain was shake-cultured for 3 days at $27^{\circ} \mathrm{C}$ in $125 \mathrm{ml}$ of the maltose soybean medium placed in three flasks. Six hundred and twenty five milligrams of unlabeled kasugamycin was added to the first flask; 1,350 mg of kasugamycin to the second flask and none to the third flask. These flasks were further shake-cultured for 24 hours. Then, $5 \mathrm{ml}$ of the cultured broth was taken from each flask and placed in a $100 \mathrm{ml}$ flask. After addition of $2.0 \mu \mathrm{c}$ of $\mathrm{U}^{-14} \mathrm{C}-\mathrm{g}$ lycine or $\mathrm{U}-{ }^{14} \mathrm{C}-$ glucose, each flask was further shake-cultured for 165 minutes. Kasugamycin produced in each flask was isolated by Amberlite $\mathrm{XE}-100$ resin process and the incorporation (total radioactivity in kasugamycin in the broth/U-14 $\mathrm{C}-\mathrm{glycine}$ or $\mathrm{U}-{ }^{14} \mathrm{C}-\mathrm{glu}-$ cose added) was determined. Then, the results were as follows: without addition of

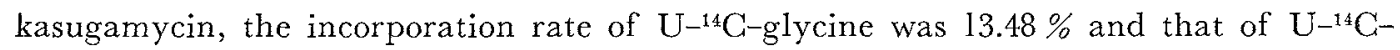
glucose, $7.45 \%$; with addition of $5.0 \mathrm{mg} / \mathrm{ml}$ of kasugamycin, the incorporation of ${ }^{14} \mathrm{C}^{-}$ glycine was $13.95 \%$ and that of ${ }^{14} \mathrm{C}-$ glucose $7.11 \%$; with addition of $10.0 \mathrm{mg} / \mathrm{ml}$ of kasugamycin, the incorporation of ${ }^{14} \mathrm{C}-$ glycine was $12.93 \%$, and that of ${ }^{14} \mathrm{C}-$ glucose $7.15 \%$. Thus, incorporation of ${ }^{14} \mathrm{C}-$ glycine and ${ }^{14} \mathrm{C}-$ glucose into kasugamycin during production of this antibiotic was not influenced by $5 \mathrm{mg} / \mathrm{ml}$ or $10 \mathrm{mg} / \mathrm{ml}$ of kasugamycin indicating that kasugamycin in the cultured liquid exhibits no inhibition of kasugamycin biosynthesis.

Consumption of glucose, gylcine and myo-inositol, and their incorporation into kasugamycin :

S. kasugaensis was shake-cultured in $125 \mathrm{ml}$ of the maltose-soybean medium at $27^{\circ} \mathrm{C}$ for 3 days and $10 \mathrm{ml}$ of the cultured broth was transferred to a $100 \mathrm{ml}$ flask. To the cultured broth in a new flask, $10.0 \mu \mathrm{c}$ of $\mathrm{U}^{11} \mathrm{C}-$ glucose, $2.0 \mu \mathrm{c}$ of ${ }^{1-{ }^{14}} \mathrm{C}-$ glycine, or $2.5 \mu \mathrm{c}$ of $\mathrm{U}-{ }^{14} \mathrm{C}-\mathrm{myo}$-inositol was added and shake-cultured. From each flask, 0.5 $\mathrm{ml}$ of the cultured broth was taken $0,5,10,20,30,40,50,60,120,240$ (or 200), and 1,560 (or 1,200) minutes thereafter and centrifuged. Kasugamycin was isolated from the supernatant by high voltage paper electrophoresis and XE-100 chromatography. As shown in Fig. 1 , after adding $\mathrm{U}^{-14} \mathrm{C}-$ glucose, the radioactivity of the spot (point of application) corresponding to glucose rapidly decreased. Moreover, paper chromatography using $n$-butanol - pyridine - water ( $6: 4: 3$, ascending) and acetone - water (85: 15 descending) showed that after 50 minutes fermentation a radioactive compound remaining at the "glucose spot" of high voltage electrophoretogram was not glucose. $\mathrm{U}^{14} \mathrm{C}-$ Glucose had disappeared 50 minutes after its addition. All radioactivity present in the "kasugamycin spot" on a paper electrophoretogram was something other than kasugamycin. The radioactive compound different from kasugamycin showed a diffferent behavior on $\mathrm{XE}-100$ resin. It passed the resin column in $\mathrm{NH}_{4}{ }^{+}$form and was identified as glutamic acid by high voltage paper electrophoresis at $3,500 \mathrm{~V}$ for 15 minutes and paper chromatography with n-butanol-acetic acid-water $(4: 1: 1)$ or $n$-butanol-ethanol-water $(4: 2: 1)$. As shown in Fig. 1, the biosynthesis of kasugamycin from glucose proceeded rapidly in parallel with the rapid consumption of glucose and, after the glucose was completely consumed, the rate of synthesis of 
kasugamycin from added glucose became slower. Synthesis from glucose ceased $60 \sim 120$ minutes after addition of glucose. The incorporation of glucose into kasugamycin was about $8 \%$. In this experiment, glucose was added to the maltose-soybean medium at 3 days of the shaking culture, that is, at the production phase of kasugamycin in this medium, and therefore, all materials necessary for synthesis of kasugamycin must exist in the medium. These results suggest that about $8 \%$ of glucose added is converted to intermediates useful for synthesis of kasugamycin and the rest is rapidly metabolized to compounds which are not utilized for synthesis of kasugamycin.

The results of the experiment in which $1{ }^{11} \mathrm{C}$-glycine was added are shown in Fig. 2. The "kasugamycin spot" from high voltage paper electrophoresis was extracted with water and the extract was subjected to XE-100 resin chromatography. Then, besides the radioactive kasugamycin, another radioactive compound was isolated. This compound was identified as serine by paper chromatography using $n$-butanolacetic acid-water $(4: 1: 1)$ and $n$-butanol-ethanol-water $(4: 2: 1)$. As shown in Fig. 2 , synthesis of kasugamycin from glycine proceeded rapidly in parallel with the rapid consumption of glycine. Incorporation of two carbons of glycine into kasugamycin ceased when glycine disappeared from the culture liquid. Glycine was more rapidly converted to serine than to kasugamycin. The results in Fig. 2 indicate that this serine is not useful for the synthesis of kasugamycin. The reason why addition of glycine did not increase the yield of kasugamycin is now clear. Glycine disappears rapidly from the medium and compounds which are derived from glycine and remain

Fig. 2. Time course of incorporation of

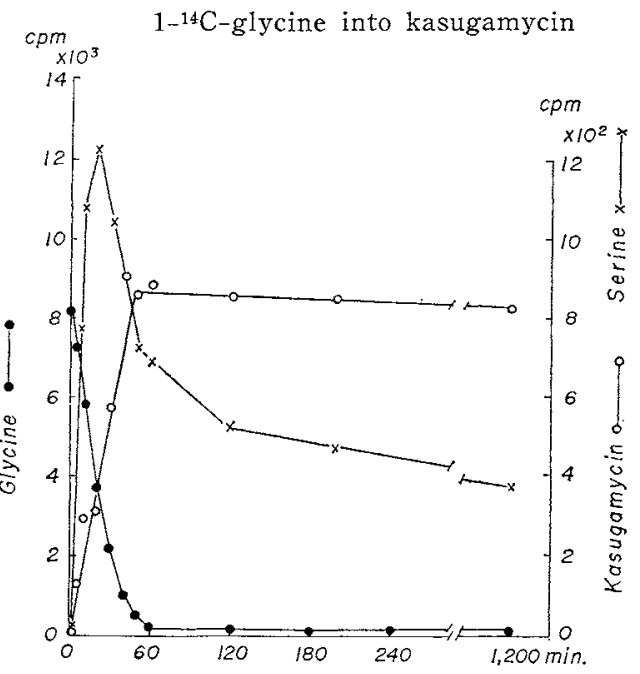

Fig. 3. Time course of incorporation of $\mathrm{U}^{14} \mathrm{C}-\mathrm{myo}$-inositol into

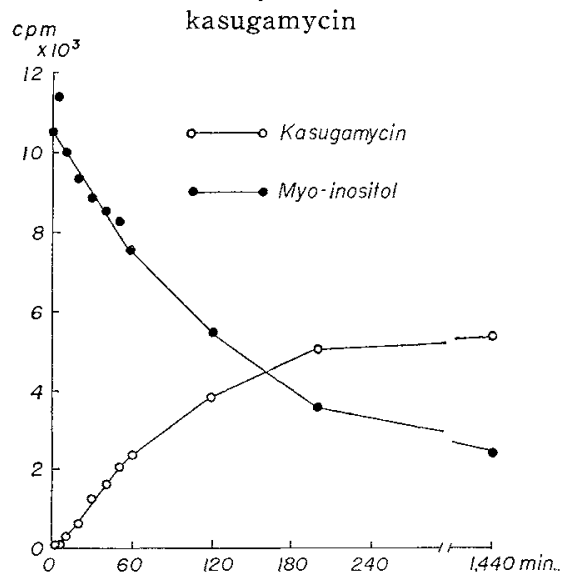


in the medium are useless for the synthesis of kasugamycin.

Fig. 3 shows the results of studies on the synthesis of kasugamycin from myoinositol. In parallel with decrease of myo-inositol in the cultured liquid, kasugamycin was synthesized from myo-inositol until 200 minutes after addition of myo-inositol. After 200 minutes of the addition about $26 \%$ of myo-inositol added still remained in the cultured liquid, but it was not utilized for synthesis of kasugamycin. Perhaps. myo-inositol outside the cells of a kasugamycin-producing organism may cause some changes in the enzyme patterns that inhibit the use of myo-inositol in the medium. If so, addition of myo-inositol would not increase the yield of kasugamycin.

Productivity of cells at various growing phases:

$S$. kasugaensis was shake-cultured in $70 \mathrm{ml}$ of a medium consisting of soybean oil. $7.5 \%$ and soybean meal $8,0 \%$ in a $300-\mathrm{ml}$ flask on a rotary shaking machine at $27^{\circ} \mathrm{C}$ and 220 r.p.m. Five $\mathrm{ml}$ of the cultured broth after 3 days, 7 days or 10 days were transferred into a $100 \mathrm{ml}$ flask. To $5 \mathrm{ml}$ of the cultured broth in each flask, $2.0 \mu \mathrm{c}$ of $\mathrm{U}-{ }^{14} \mathrm{C}-\mathrm{glucose}, 2.0 \mu \mathrm{c}$ of $\mathrm{U}-{ }^{14} \mathrm{C}-\mathrm{glycine}$, or $1.0 \mu \mathrm{c}$ of myo-inositol was added and fermented for 100 minutes at $27^{\circ} \mathrm{C}$ on a reciprocal shaking machine. From the cultured broth of each flask, kasugamycin was cellected by high voltage paper electrophoresis followed: by the XE-100 resin process. As shown in Table 2, all the ${ }^{14} \mathrm{C}$-compounds showed. the highest incorporation into kasugamycin when added at 3 days of the culture. This result indicates that the production rate of kasugamycin per 100 minutes is the highest at 3 days and the slowest at 10 days. These results conform to the production of kasugamycin, that is, $1,500 \mathrm{mcg} / \mathrm{ml}$ at 3 days, $7,100 \mathrm{mcg} / \mathrm{ml}$ at 6 days and 10,200 $\mathrm{mcg} / \mathrm{ml}$ at 10 days. The ratios of the incorporation of myo-inositol to the incorporation of glucose or to that of glycine are shown in the same table. The ratios to glucose at 6 and 10 days are higher than that at 3 days. The ratios to glycine at 3 and 6 days are almost the same, but smaller than that at 10 days. These results suggest that the capacity to utilize glycine for synthesis of the carboxyformidoyl group of kasugamycin was equal at 3 and 6 days but less at 10 days, and the capacity to utilize glucose for synthesis of the kasugamine moiety became less when the cultivation was prolonged for 6 or 10 days.

In another experiment, $5 \mathrm{ml}$ of the cultured broth was taken at 3,6 and 10 days

Table 2. Productivity of cells at various growth phases

\begin{tabular}{|c|c|c|c|c|c|c|c|c|}
\hline \multirow{4}{*}{ days } & \multirow{4}{*}{$\begin{array}{c}\text { Potency of } \\
\text { kasugamycin } \\
\mathrm{mcg} / \mathrm{ml}\end{array}$} & \multicolumn{7}{|c|}{ Percent incorporation } \\
\hline & & \multicolumn{5}{|c|}{ with cultured broth } & \multicolumn{2}{|c|}{ with washed cells $s_{*}$} \\
\hline & & \multirow{2}{*}{$\begin{array}{l}\text { U- }{ }^{14} \mathrm{C}- \\
\text { Glucose } \\
\text { (a) }\end{array}$} & \multirow{2}{*}{$\begin{array}{c}U-{ }^{14} \mathrm{C}-\mathrm{Myo}- \\
\text { inositol } \\
\text { (b) }\end{array}$} & \multirow{2}{*}{$\begin{array}{c}\text { U- }{ }^{14} \mathrm{C}- \\
\text { Glycine } \\
\text { (c) }\end{array}$} & \multicolumn{2}{|c|}{$\begin{array}{c}\text { Relative } \\
\text { ratio }\end{array}$} & \multirow{2}{*}{$\begin{array}{l}\mathrm{U}-{ }^{14} \mathrm{C}- \\
\text { Glucose }\end{array}$} & \multirow{2}{*}{$\begin{array}{l}\mathrm{U}-{ }^{14} \mathrm{C}- \\
\text { Glycine }\end{array}$} \\
\hline & & & & & $b / a$ & $\mathrm{~b} / \mathrm{c}$ & & \\
\hline 3 & 1.500 & 20.30 & 80.41 & 21.61 & 4.0 & 3.7 & 11.95 & 19.59 \\
\hline 6 & 7,100 & 10.69 & 55.72 & 16.82 & 5.2 & 3.3 & 10.58 & 13.05 \\
\hline 10 & 10,200 & 6.45 & 43.55 & 9.16 & 6.8 & 4.8 & 6.58 & 9.01 \\
\hline
\end{tabular}

* Suspended in a basal medium consisted of maltose $5.0 \mathrm{mg}$, myo-inositol $5.0 \mathrm{mg}$, glycine $5.0 \mathrm{mg}$ (in case of $\mathrm{U}-{ }^{14} \mathrm{C}$-glycine, omitted), L-glutamine $5.0 \mathrm{mg}$ and $\mathrm{MgSO}_{4} \cdot 7 \mathrm{H}_{2} \mathrm{O} 5.0 \mathrm{mg}$. 
of the shaking culture as above described and the cells were collected by centrifugation, washed once with $5 \mathrm{ml}$ of physiological saline and suspended in $5 \mathrm{ml}$ of a medium containing $5 \mathrm{mg}$ maltose, $5 \mathrm{mg}$ myo-inositol, $5 \mathrm{mg}$ glycine, $5 \mathrm{mg}$ L-glutamine and $5 \mathrm{mg} \mathrm{MgSO}_{4} \cdot 7 \mathrm{H}_{2} \mathrm{O}$. Then $2.0 \mu \mathrm{c}$ of $\mathrm{U}-{ }^{14} \mathrm{C}-$ glucose was added and shake-cultured for 100 minutes. Similarly, the cells were suspended in the same medium without unlabeled glycine, but $2.0 \mu \mathrm{c}$ of $\mathrm{U}^{-14} \mathrm{C}$-glycine. From these shake-cultured broths, kasugamycin was isolated by high voltage paper electrophoresis followed by the XE100 resin process and the incorporation of $\mathrm{U}-{ }^{14} \mathrm{C}-$ glucose and $\mathrm{U}-{ }^{14} \mathrm{C}-$ glycine was determined. As shown in Table 2, the incorporation was the highest in 3-day cells and lowest in 10-day cells. This also indicates that the productivity of kasugamycin is the highest at 3 days and the lowest at 10 days. These results suggest that if new medium is fed during fermentation to increase the yield of kasugamycin, it must be started early fermentation to maintain high productivity and to keep a balance of nutrients in the culture medium.

Productivity of kasugamycin-producing organism cultured in various media:

$S$. kasugaensis was shake-cultured in $125 \mathrm{ml}$ portions of 4 kinds of media as shown in Table 3, and from each flask $2.5 \mathrm{ml}$ of the cultured broth was taken and placed in a $100 \mathrm{ml}$ flask with fresh medium. Then $1.0 \mu \mathrm{c}$ of $\mathrm{U}-{ }^{14} \mathrm{C}-$ glucose, $1.0 \mu \mathrm{c}$ of $\mathrm{U}^{14} \mathrm{C}-$ glycine, $1.0 \mu \mathrm{c}$ of $\mathrm{U}-{ }^{14} \mathrm{C}-\mathrm{myo}$-inositol, or $2^{2-14} \mathrm{C}$-acetate was added and shake-cultured for 120 minutes. Kasugamycin was collected by the methods above described and the incorporation into kasugamycin of the ${ }^{14} \mathrm{C}$-compounds added was determined. The result is shown in Table 4 . At the time indicated, $1,260 \mathrm{mcg} / \mathrm{ml}, 560 \mathrm{mcg} / \mathrm{ml}, 240 \mathrm{mcg} /$ $\mathrm{ml}$ or $70 \mathrm{mcg} / \mathrm{ml}$ of kasugamycin was produced in Medium 3 (soybean oil-soybean meal), Medium 4 (maltose-soybean meal), Medium 2 (maltose-ammonia) or Medium 1 (glucose-soybean meal) respectively. The incorporation of glucose into kasugamycin Table 3. Medium composition and kasugamycin production

\begin{tabular}{|c|c|c|c|c|c|c|c|c|c|}
\hline \multirow[b]{2}{*}{ Medium 1} & \multicolumn{6}{|c|}{ Composition $(\%)$} & \multicolumn{2}{|c|}{$\begin{array}{l}\text { Cultural } \\
\text { condition }\end{array}$} & $\begin{array}{l}\text { Kasugamycin } \\
\text { production } \\
(\mathrm{mcg} / \mathrm{mI})\end{array}$ \\
\hline & $\begin{array}{l}\text { Glucose } \\
\text { Soybean meal }\end{array}$ & $\begin{array}{l}1.5 \\
1.5\end{array}$ & $\begin{array}{l}\mathrm{NaCl} \\
\mathrm{MgSO}_{4} \cdot 7 \mathrm{H}_{2} \mathrm{O}\end{array}$ & $\begin{array}{l}0.3 \\
0.1\end{array}$ & $\mathrm{~K}_{2} \mathrm{HPO}_{4}$ & 0.1 & $\begin{array}{l}125 \mathrm{ml} \\
(\mathrm{pH} 4.2)\end{array}$ & $\begin{array}{l}27^{\circ} \mathrm{C} \\
3 \text { days }\end{array}$ & 70 \\
\hline Medium 2 & $\begin{array}{l}\text { Maltose } \\
\left(\mathrm{NH}_{4}\right)_{2} \mathrm{HPO}_{4}\end{array}$ & $\begin{array}{l}7.0 \\
1.0\end{array}$ & $\begin{array}{l}\mathrm{K}_{2} \mathrm{HPO}_{4} \\
\mathrm{MgSO}_{4} \cdot 7 \mathrm{H}_{2} \mathrm{O}\end{array}$ & $\begin{array}{l}0.1 \\
0.05\end{array}$ & & & $\begin{array}{l}125 \mathrm{ml} \\
(\mathrm{pH} 5.6)\end{array}$ & $\begin{array}{l}27^{\circ} \mathrm{C} \\
4 \text { days }\end{array}$ & 240 \\
\hline Medium 3 & Esusan meat & 6.5 & Soybean oil & 6.5 & & & $\begin{array}{c}70 \mathrm{ml} \\
(\mathrm{pH} 6.0)\end{array}$ & $\begin{array}{l}27^{\circ} \mathrm{C} \\
6 \text { days }\end{array}$ & 1,260 \\
\hline Medium 4 & $\begin{array}{l}\text { Maltose } \\
\text { Soybean meal }\end{array}$ & $\begin{array}{l}1.5 \\
1.5\end{array}$ & $\begin{array}{l}\mathrm{NaCl} \\
\mathrm{MgSO}_{4} \cdot 7 \mathrm{H}_{2} \mathrm{O}\end{array}$ & $\begin{array}{l}0.3 \\
0.1\end{array}$ & $\mathrm{~K}_{2} \mathrm{HPO}_{4}$ & 0.1 & $\begin{array}{l}125 \mathrm{ml} \\
(\mathrm{pH} 6.0)\end{array}$ & $\begin{array}{l}27^{\circ} \mathrm{C} \\
3 \text { days }\end{array}$ & 560 \\
\hline
\end{tabular}

is higher in parallel with the production of kasugamycin. The incorporation of myo-inositol has no relation with the production of kasugamycin. However, it must be noted that the incorporation of glucose was highest in Medium 3 which contained soybean oil as the
Table 4. Effect of medium composition on incorporation of various ${ }^{14} \mathrm{C}$-compounds into kasugamycin

\begin{tabular}{l|c|c|c|c}
\hline & \multicolumn{4}{|c}{ Incorporation \% } \\
\cline { 2 - 5 } & $\begin{array}{c}\text { Medium } \\
1\end{array}$ & $\begin{array}{c}\text { Medium } \\
2\end{array}$ & $\begin{array}{c}\text { Medium } \\
3\end{array}$ & $\begin{array}{c}\text { Medium } \\
4\end{array}$ \\
\hline U-14C-Glucoce & 0.32 & 1.23 & 10.01 & 4.32 \\
U-14C-Myo-inosito1 & 54.62 & 5.88 & 43.29 & 61.86 \\
U-14C-Glycine & 7.07 & 2.98 & 10.97 & 18.47 \\
$2-{ }^{14} \mathrm{C}$-Acetate & 0.15 & 0.75 & 0.34 & 0.29 \\
\hline
\end{tabular}


main carbon source. The other media contained maltose or glucose as the carbon: source. It is interesting that the higher production was observed in Medium 2 containing maltose as the carbon source and ammonium phosphate as the nitrogen source. than in Medium 1 containing glucose and soybean meal. The production of kasugamycin in the glucose medium is the lowest, but the incorporation of myo-inositol is. as high as in Medium 4 and the incorporation of glycine is also relatively high. It: suggests that the mycelium in the glucose medium has enough activity to synthesize kasugamycin but constituents in the media at 3 days may not be favorable for synthesis of kasugamycin. Glucose is considered to be taken into cells as glucose. 6-phosphate and metabolized in several directions, for instances, to myo-inositol, to. glucosamine, to KREBS cycle acids and amino acids. The balance of the glucose metabolism in various directions may not be favorable for the synthesis of kasugamycin.. The result observed in Medium 2 (maltose-ammonia) encourages us to study suitablesynthetic media for production of kasugamycin.

Optimum $\mathrm{pH}$ of media for incorporation of glucose, glycine and myo-inositol. into kasugamycin :

S. kasugaensis was shake-cultured in the maltose-soybean medium in a $500 \mathrm{ml}$ flask at $27^{\circ} \mathrm{C}$ for 72 hours. Then $5.0 \mathrm{ml}$ of the broth was taken and placed in a $100 \mathrm{ml}$ flask and $0.5 \mathrm{ml}$ of $\mathrm{M} / 2$ phosphate buffer of various $\mathrm{pH}$ was added. To the cultured. broth with phosphate buffers of various $\mathrm{pH}$, $1.0 \mu \mathrm{c}$ of $\mathrm{U}-{ }^{14} \mathrm{C}-\mathrm{glucose}, 0.6 \mu \mathrm{c}$ of $\mathrm{U}^{14} \mathrm{C}-\mathrm{myo}-$ inositol or $2.5 \mu \mathrm{c}$ of $\mathrm{U}-{ }^{14} \mathrm{C}-$ glycine was added and shake-cultured at $27^{\circ} \mathrm{C}$ for 3 hours. Kasugamycin in the broth was collected by high voltage paper electrophoresis followed by the $\mathrm{XE}-100$ resin process and the incorporation into kasugamycin was studied. As shown in Fig. 4 , the incorporation of ${ }^{14} \mathrm{C}-$ glucose and ${ }^{14} \mathrm{C}-\mathrm{myo}^{-}$ inositol were almost the same at $\mathrm{pH} 5.5 \sim 8.0$, but the incorporation of glycine was influenced by $\mathrm{pH}$. It was highest at $\mathrm{pH} 6.0 \sim 7.0$ and

Fig. 4. Effect of $\mathrm{pH}$ on incorporation of ${ }^{14} \mathrm{C}$-compounds into kasugamycin

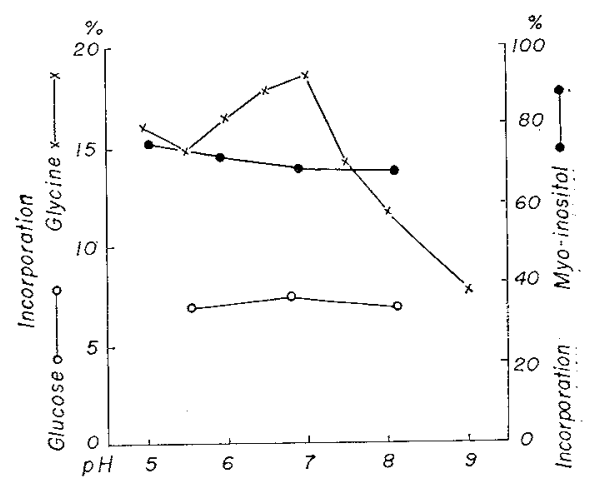
decreased when the $\mathrm{pH}$ exceeded 7.0. This $\mathrm{pH}$ optimum for incorporation of glycine. into kasugamycin agrees with the optimum $\mathrm{pH}$ during the production phase of: kasugamycin in fermenters.

Incorporation of ${ }^{14} \mathrm{C}-$ glucose, ${ }^{14} \mathrm{C}-$ glycine and ${ }^{14} \mathrm{C}$-myo-inositol into kasugamycin: under varying aeration conditions:

S. kasugaensis was shake-cultured in $125 \mathrm{ml}$ of the maltose-soybean meal medium: in a $500-\mathrm{ml}$ flask at $27^{\circ} \mathrm{C}$ for 3 days and $5.0 \mathrm{ml}$ of the cultured broth was placed in a $\mathrm{L}$ tube (diameter $18 \mathrm{~mm}$ and length $150 \mathrm{~mm}$ ). After addition of $1.0 \mu \mathrm{c}$ of $\mathrm{U}^{-14} \mathrm{C}-$ glucose, $0.5 \mu \mathrm{c}$ of $\mathrm{U}^{-14} \mathrm{C}-\mathrm{myo}$-inositol or $1.0 \mu \mathrm{c}$ of $\mathrm{U}^{-14} \mathrm{C}-$ glycine, it was shake-cultured. at $17.5^{\circ} \mathrm{C}, 20^{\circ} \mathrm{C}, 27^{\circ} \mathrm{C}, 30^{\circ} \mathrm{C}$ or $37^{\circ} \mathrm{C}$ for 60 minutes with a Monod shaker. Kasugamycin: in the cultured broth was isolated by the $\mathrm{XE}-100$ resin process followed by carbon: chromatography and its radioactivity was measured. The result is shown in Table 5 .. 
The incorporation of myo-inositol suggests that the pathway from myo-inositol to the $\mathrm{D}$-inositol moiety of kasugamycin is most active at $27.0^{\circ} \mathrm{C}$ and still active at $20.0^{\circ} \mathrm{C}$, $30.0^{\circ} \mathrm{C}$ or $37.0^{\circ} \mathrm{C}$. The incorporation of ${ }^{14} \mathrm{C}$-glucose suggests that the pathway from glucose to kasugamine is active at $20 \sim 37^{\circ} \mathrm{C}$. The pathway from glycine to the carboxyformidoyl group of kasugamycin is most temperature-sensitive and probably most active at $27 \sim 30^{\circ} \mathrm{C}$.

Table 5. Effect of temperature on incorporation of ${ }^{14} \mathrm{C}-$ compounds into kasugamycin under aerobic conditions

\begin{tabular}{l|r|c|c}
\hline \multirow{2}{*}{ Temperature } & \multicolumn{3}{|c}{ Persent incorporation } \\
\cline { 2 - 4 } & $\begin{array}{c}\text { U-14C- } \\
\text { Glucose }\end{array}$ & $\begin{array}{c}\text { U-14C-Myo- } \\
\text { inositol }\end{array}$ & $\begin{array}{c}\text { U-14C- } \\
\text { Glycine }\end{array}$ \\
\hline $17.5^{\circ} \mathrm{C}$ & 5.77 & 55.81 & 6.98 \\
20.0 & 9.37 & 62.89 & 11.23 \\
27.0 & 10.65 & 79.66 & 20.44 \\
30.0 & 9.62 & 68.91 & 21.22 \\
37.0 & 9.33 & 68.91 & 18.51 \\
\hline
\end{tabular}

Table 6. Effect of temperature on incorporation of ${ }^{14} \mathrm{C}$-compounds into kasugamycin under less aerobic conditions

\begin{tabular}{l|c|c|c}
\hline \multirow{2}{*}{ Temperature } & \multicolumn{3}{|c}{ Percent incorporation } \\
\cline { 2 - 4 } & $\begin{array}{c}\text { U-14C- } \\
\text { Glucose }\end{array}$ & $\begin{array}{c}\text { U-14C-Myo- } \\
\text { inositol }\end{array}$ & $\begin{array}{c}\text { U-14 }{ }^{14} \text { G1ycine } \\
\text { Glycin }\end{array}$ \\
\hline $20^{\circ} \mathrm{C}$ & 6.03 & 92.00 & 15.14 \\
27 & 2.43 & 70.82 & 7.47 \\
30 & 1.61 & 65.15 & 4.79 \\
37 & 1.15 & 22.85 & 2.34 \\
\hline
\end{tabular}

However when the incorporation was examined under less aerobic conditions, the result was markedly different. Two $\mathrm{ml}$ of the three day-cultured broth was placed in a test tube with a cotton plug and, after addition of a radioactive compound, shaken while standing with a "Monoshin" shaker. The radioactive compounds added were as follows: $1.0 \mu \mathrm{c}$ of $\mathrm{U}^{14} \mathrm{C}-\mathrm{glucose}, 0.5 \mu \mathrm{c}$ of $\mathrm{U}-{ }^{14} \mathrm{C}-\mathrm{myo}$-inositol and $0.75 \mu \mathrm{c}$

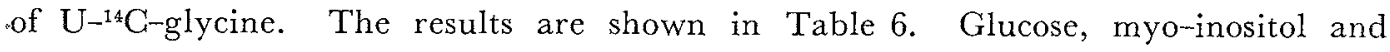
glycine were most highly incorporated at the lowest temperature, that is, $20^{\circ} \mathrm{C}$.

These results indicate that the optimal temperature for production of kasugamycin is dependent on aeration of the medium.

\section{References}

1) Fukagawa, Y.; T. SaWa, T. Takeuchi \& H. Umezawa : Studies on biosynthesis of kasugamycin. I. Biosynthesis of kasugamycin and the kasugamine moiety. J. Antibiotics $21: 50 \sim 54,1968$

2) FukagaWa, Y.; T. SaWA, T. TAkeuchi \& H. UMEZAWA : Biosynthesis of kasugamycin. II. Biosynthesis of the two-carbon side chain of kasugamycin. J. Antibiotics $21: 182 \sim 184,1968$

3) Fukagawa, Y.; T. SaWa, T. TakeUchi \& H. UMEZaWA: Studies on biosynthesis of kasugamycin. III. Biosynthesis of the D-inositol moiety. J. Antibiotics $21: 185 \sim 188,1968$

4) Fukagawa, Y.; T. SAWA, I. Homma, T. TAKEuChi \& H. UmezaWa: Studies on biosynthesis of kasugamycin. IV. Biosynthesis of the kasugamine moiety from $\left[1-{ }^{14} \mathrm{C}\right]$-glucosamine and $[1$, 2 or $\left.6^{-14} \mathrm{C}\right]$-glucose. J. Antibiotics $21: 358 \sim 360,1968$

5) Fukagawa, Y.; T. Sawa, I. Homma, T. Takeudhi \& H. Umezawa: Studies on biosynthesis of kasugamycin. V. Biosynthesis of the amidine group. J. Antibiotics $21: 410 \sim 412,1968$ 